\title{
Original article (Orijinal araştırma) \\ Investigation into control of cherry fruit fly, Rhagoletis cerasi (L., 1758) (Diptera: Tephritidae), in organic cherry production ${ }^{1}$
}

\author{
Organik kiraz yetiştiriciliğinde Kiraz sineği Rhagoletis cerasi (L., 1758) (Diptera: \\ Tephritidae)'nin mücadelesi üzerine araştırmalar
}

Burcu ÖZBEK ÇATAL ${ }^{*}$

\author{
Mehmet Rifat ULUSOY 3
}

\begin{abstract}
The study was conducted at two locations, Pozantı (Adana) and Darboğaz (Ulukışla, Niğde) in 2015-2017. It aimed to determine the effects of the emergence time of cherry fruit fly, Rhagoletis cerasi (L., 1758) (Diptera: Tephritidae), the dynamics of adult flight and the control methods that could be used in organic cherry production. It investigated the effectiveness of netting trees, textile mulch, mass capture, plant-based insecticides and insecticide application against cherry fruit fly. Population monitoring revealed that the population of cherry fruit fly was low at Pozantı and slightly higher at Darboğaz. Clear statistical differences were observed between the untreated control and the treatments evaluated. The most effective control was obtained from with netting ( $100 \%$ efficacy). It was concluded that the other methods evaluated could be useful in organic cherry production.
\end{abstract}

Keywords: Alternative control, cherry, organic farming, Rhagoletis cerasi, Turkey

\section{Öz}

Çalışma, 2015-2017 yılları arasında Pozantı (Adana) ve Darboğaz (Ulukışla/Niğde) olmak üzere iki alanda yürütülmüştür. Kiraz sineği [Rhagoletis cerasi (L., 1758) (Diptera: Tephritidae)]'nin ortaya çıkış zamanı, popülasyon takibi ve Kiraz sineğine karşı organik kiraz yetiştiriciliğinde kullanılabilecek mücadele yöntemlerinin etkilerinin belirlenmesi amaçlanmıştır. Kiraz sineğine karşı mücadelede ağaçları örten net, malç tekstili, kitlesel yakalama tekniği, bitkisel kökenli insektisit ve insektisit uygulamalarının etkinliği araşıııımışıı. Yapılan popülasyon takibi, Kiraz sineği popülasyonunun Pozantı'da düşük, Darboğaz'da biraz daha yüksek olduğunu ortaya koymuştur. Denemeye alınan mücadele yöntemleri ile kontrol karşılaşıııldığında aralarında istatistiksel olarak fark olduğu gözlenmiştir. En etkili mücadele yöntemi net uygulaması (\%100 etki) ile elde edilmiştir. Denemeye alınan diğer mücadele yöntemlerinin de organik kiraz yetiştiriciliğinde yararlı olabileceği sonucuna varılmıştır.

Anahtar sözcükler: Alternatif mücadele, kiraz, organik tarım, Rhagoletis cerasi, Türkiye

\footnotetext{
1 This study is presented as oral in $1^{\text {st }}$ International Organic Agriculture and Biodiversity Symposium (27-29 September 2017, Bayburt, Turkey) and published as abstract in the abstract book.

2 Çukurova University, Pozantı Vocational School, Department of Plant and Animal Production, 01470, Pozantı, Adana, Turkey

${ }^{3}$ Çukurova University, Department of Plant Protection, Faculty of Agriculture, 01330, Balcalı, Adana, Turkey

* Corresponding author (Sorumlu yazar) e-mail: bozbek@cu.edu.tr

Received (Alınış): 22.01.2018 Accepted (Kabul ediliş): 31.03.2018Ｐublished Online (Çevrimiçi Yayın Tarihi): 30.04 .2018
} 


\section{Introduction}

The European cherry fruit fly belongs to the family of Tephritidae, which has a worldwide distribution of about 4,000 described species in about 500 genera (Headrick \& Goeden, 1998). The genus Rhagoletis Loew, 1862 includes about 65 known species (White \& Elson-Harris, 1992). Most species are oligophages, attacking only a few closely related host plants. In addition to Rhagoletis cerasi (L., 1758), the American cherry fruit fly species, Rhagoletis cingulata (Loew, 1862), Rhagoletis indifferens Curran, 1932 and Rhagoletis fausta (Osten Sacken, 1877), as well as the apple maggot, Rhagoletis pomonella (Walsh, 1867), the blueberry maggot, Rhagoletis mendax Curran, 1932, and the walnut infesting species, Rhagoletis completa Cresson, 1929 and Rhagoletis suavis (Loew, 1862), are pest insects of economic importance (Boller \& Prokopy, 1976). Host plants of $R$. cerasi include various Prunus spp. (P. cerasus, $P$. avium, P. serotina, P. mahaleb; Rosaceae) (Thiem, 1934; Leski, 1963) as well as Lonicera spp. (Lonicera xylosteum and Lonicera tatarica; Caprifoliaceae) (Mik, 1898; Thiem, 1932, 1939; Wiesmann, 1938; Ranner, 1988; White \& Elson-Harris, 1992). The European cherry fruit fly is the most serious pest in cherry orchards in Europe and Turkey, causing fruit damage and yield losses (Ulusoy et al., 1999; Vogt, 2002; Daniel \& Wyss, 2003). The adult flies emerge from the soil in May to June and begin to lay eggs under skin of cherry fruit about $10 \mathrm{~d}$ after emergence. The larvae develop inside the cherries. The larvae leave the fruit, drop to the soil and within hours start to pupate under the tree canopy. Cherry fruit fly is univoltine and overwinters as pupae (Wiesmann, 1934; Boller, 1966). In addition to cultural and biotechnical methods in the control of cherry fruit fly, the use of alternative substances is at the forefront of recent developments.

Production of cherry in Turkey increases slowly from year to year (about $600 \mathrm{kt}$ in 2016) and the problem with $R$. cerasi has become more important. This situation motivated us to undertake some investigations concerning $R$. cerasi flight activity and possibilities of controlling it with different kinds of management.

The aim of the organic farming system is to produce clean products (pesticide free) of good quality and also to correct the ecological balance which is deteriorated due to traditional agriculture. Therefore, chemical methods should be regarded as a last resource due to their potentially adverse effects on the environment and on consumer health. For this, eco-friendly management techniques and tools are needed. The aim of this study was mainly to develop a reduced-risk management program and predict the first emergence via trapping method of $R$. cerasi flies for optimal timing of insecticide application.

\section{Material and Methods}

In this research natural populations of $R$. cerasi in orchards with mid-season and late cherry cultivars were studied. Materials used included yellow sticky traps $(13.5 \times 22.5 \mathrm{~cm})$ with ammonia capsules (Trece-Pherocon ${ }^{\circledR}$ AM No-Bait trap with Dual-Pak ${ }^{\mathrm{TM}}$ Supercharger $\left.{ }^{\mathrm{TM}}\right)$, netting $(0.8 \times 2 \mathrm{~mm}$ mesh size, 8$10 \%$ shade), textile mulch, azadirachtin $40 \mathrm{~g} / \mathrm{l}$ insecticide (a plant-based product) and thiacloprid $240 \mathrm{~g} / \mathrm{l}$ insecticide.

Studies were conducted in three cherry orchards, located in Çukurova University Pozantı Agricultural Research Center [Pozmer orchard 1 (174 trees) and Pozmer orchard 2 (144 trees)] in Pozantı (Adana) and in Darboğaz (Ulukışla, Niğde) (123 trees) in 2015-2016. In 2017, studies were only conducted in two orchards in Pozantı. The mass capture techniques were used to study mature flight dynamics, and plant-based insecticide, textile mulch, netting, yellow sticky traps and slow-spreading ammonia capsules were evaluated as control measures. Insecticide application was applied for comparative purposes. In the trial orchards, the trees had been fruitful for at least 5 years and the experiments were conducted in large blocks in each orchard. Five treatments were concurrently and randomly applied to blocks with eight replicates per block distributed throughout the orchard, with each replicate consisting of one tree. 


\section{Rhagoletis cerasi flight activity}

Yellow sticky traps with ammonia capsules were used to monitor the dynamics of adult flight. Three traps were set at Darboğaz and five at Pozantı (orchard 1). The traps were set before the start of adult flight at the beginning of May. They were hung on the southeast side of trees about 1.5-2 $\mathrm{m}$ above ground. The traps were checked twice per day until the first mature fly was trapped and then they were checked once per week and cleaned. The traps were removed after three consecutives zero captures. The enabled the first date of $R$. cerasi emergence to be determined for each orchard and annual adult flight graphs to be drawn.

\section{Evaluation of the methods to control Rhagoletis cerasi}

\section{Mass trapping}

The evaluation of mass trapping was done at Pozantı (orchard 2). The cherry cultivars were Sweet heart, 0900 Agriculture, Regina, Metron late and Starks gold as mid-season and late cultivars. During the study, no sprays were applied to control $R$. cerasi. Yellow sticky traps with ammonia capsules were hung at 1.5-2 $\mathrm{m}$ above ground in the mid center and outer section of the tree canopies. In order to monitor adult cherry fruit flies, two traps were hung around the orchard at the beginning of May in 2015, 2016 and 2017, and checked as described above. Mass traps were hung after first adult was seen in the traps. Traps were hung at intervals of $15-20 \mathrm{~m}$ with 3-4 trap/tree according to the size of each tree. Totally, 38 traps were used. Traps that were very dirty were replaces with new traps. Traps were left in the orchard to check whether the flight period continued after the harvest. The trapping was evaluated for 100 fruits randomly collected from the trees located in the middle part of each plot.

\section{Textile mulch and netting}

The evaluation of textile mulch and tree netting was done at Pozantı and Darboğaz on 123 and 144 trees, respectively, most at late ripening. Trees $4-5 \mathrm{~m}$ tall were protected by netting from the onset of ripening till the end of harvest. The effectiveness of two different covering methods with the anti-insect net was compared with unprotected trees. In treatment A (15 trees), mulch textile was used as a soil covering. The textile mulch was laid directly on the ground under the trees with its edges buried in the soil (Figure 1a). In treatment B (12 plants), a strip of netting was positioned vertically along both sides of the row, and then stitched to completely cover the trees, and then the netting was stitched together at the trunk level (Figure 1b).

No sprays were applied to control $R$. cerasi in any part of the orchards. The flight of the adults was monitored using one yellow sticky trap each per tree as described above. The percentage of fruits damage was assessed at the harvest time, by individually dissecting $50-100$ fruit/tree. The number of fruit collected varied depending on the total yield of the tree. Each sample was collected from around of the entire tree.

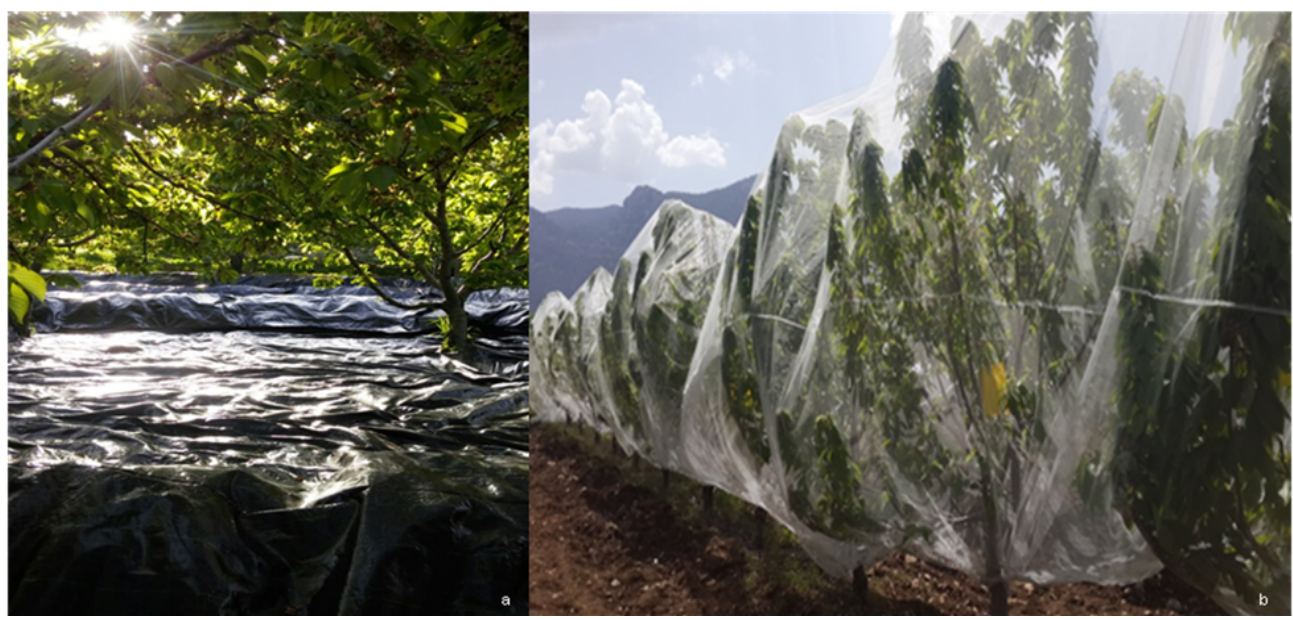

Figure 1. a) Soil covering with mulch textile, and b) tree covering with net. 


\section{Plant-based insecticide}

The assessment of a plant-based insecticide was conducted at both locations. The efficacy of the azadirachtin (plant-based) insecticide (formulated product Nimiks 4,5) was compared with insecticide containing thiacloprid as the active ingredient (formulated product Calypso OD 240). These two insecticides were applied $125 \mathrm{ml}$ and $40 \mathrm{ml} / 100$ I water, respectively, by tractor-mounted equipment and were compared with an untreated control. The flight of the adult flies was monitored with yellow sticky traps as described above. Spraying commenced after one adult fly was trapped. The spraying was repeated depending the numbers of adults trapped. The number of applications per treatment and application dates are detailed in Table1.

Table 1. Insecticide dates during 2015-2017

\begin{tabular}{lcc}
\hline Year & Pozantı & Darboğaz \\
\hline 2015 & 28 May & 21 June \\
2016 & 18 May, 1 June & 2 June, 15 June \\
2017 & 26 May, 8 June & - \\
\hline
\end{tabular}

\section{Damage assessment and data analysis}

To asses percent fruit damaged at harvest in each plot, 50-100 fruit were randomly collected, damaged and healthy fruits were counted, and the percentage of fruits damaged by $R$. cerasi was determined. The results were evaluated statistically by analysis of variance. Mean differences were compared with Duncan's test $(P<0.05)$. The efficacy of the treatments in reducing fruit damage at harvest was calculated according to Abbott (1925).

\section{Results}

\section{Rhagoletis cerasi flight activity}

Figures 2 and 3 show the pattern of flight activity at Pozantı and Darboğaz, respectively. In addition, the first adult, highest and last exit dates of $R$. cerasi are detailed in Table 2.

Table 2. First, maximum and last capture, and harvest dates and duration of capture of adult Rhagoletis cerasi at Pozantı and Darboğaz

\begin{tabular}{lccccc}
\hline & & Pozantı & & \multicolumn{2}{c}{ Darboğaz } \\
\hline First capture & 2015 & 2016 & 2017 & 2015 & 2016 \\
Maximum capture & 25 May & 18 May & 25 May & 27 May & 25 May \\
Last capture & 25 May & 18 May & 8 June & 1 July & 13 July \\
Harvest & 15 June & 15 June & 22 June & 1 July & 20 July \\
Duration of capture (d) & 15 June & 14 June & 19 June & 21 June & 29 June
\end{tabular}

At Pozantı, the first adult fly captures occurred on 25 May 2017, 18 May 2016 and 25 May 2015. In 2015 and 2016, the maximum captures on the same dates, where as it was 2 weeks later during the warm and sunny period from 1 May to 8 June, 2017. Figure 2 shows the flight activity for each year. Peak captures were recorded between 18 May to 8 June 2015, 11 May to 8 June 2016, and 1 to 22 June 2017 when the climatic conditions were favorable. The subsequent decline in numbers was because of climatic conditions were no longer suitable. The decline was monitored until the last capture, which was observed at the end of June in three years. 
At Darboğaz, the first captures occurred on 27 May 2015 and 25 May 2016 when the fruits were small and still green. The maximum catches were on 1 July 2015 and 13 July 2016, both after harvest. The last adult capture was in July in both two years. In 2015, the population of $R$. cerasi accepted as zero quarantine tolerance was found to be low relative to 2016. In 2016, captures were made had been registered from 25 May to 20 July with two peaks (Figure 3 ). After the harvest, some adults continued to be captured.
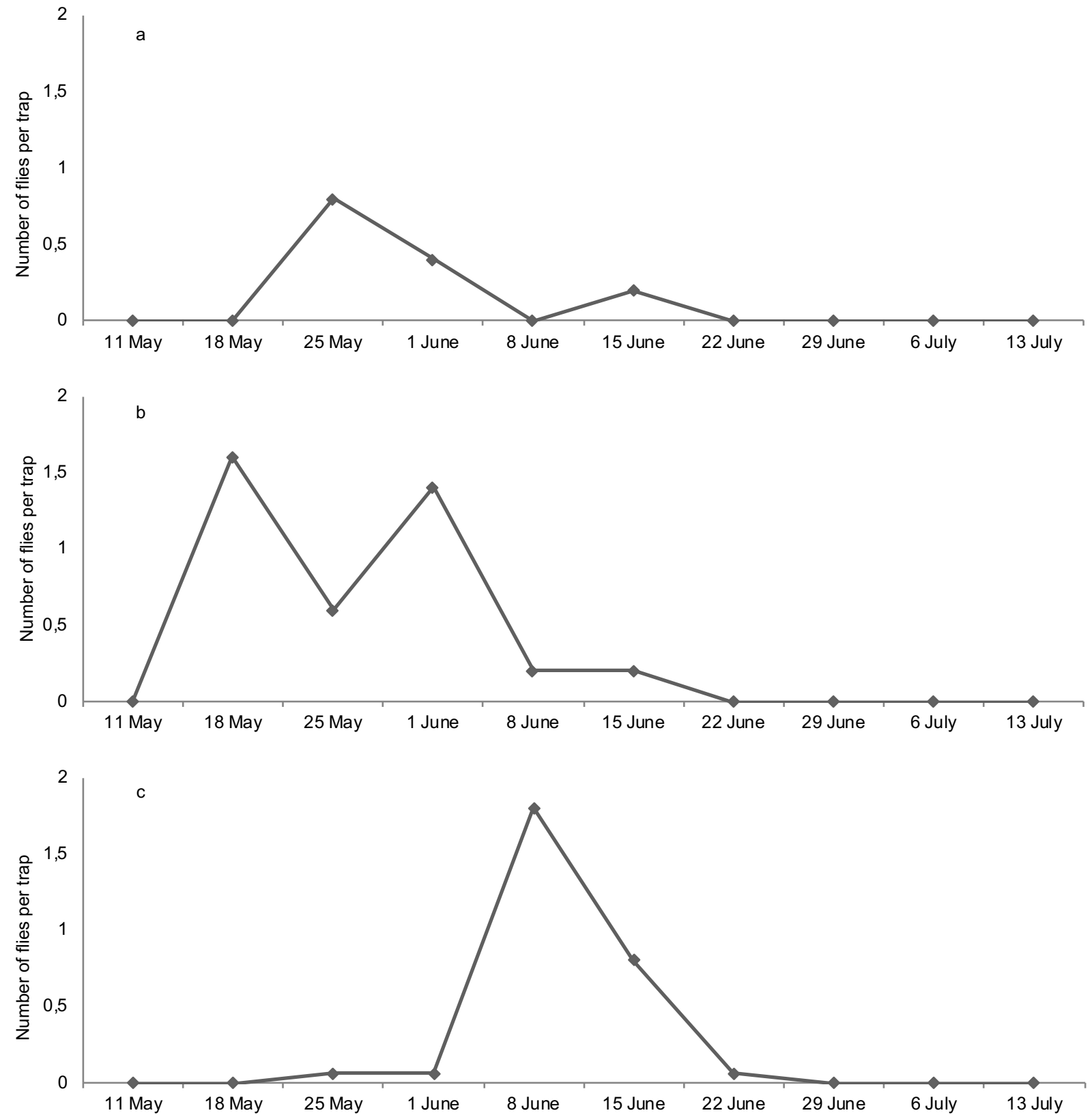

Figure 2. Flight activity of Rhagoletis cerasi at Pozantı in a) 2015, b) 2016, and c) 2017. 

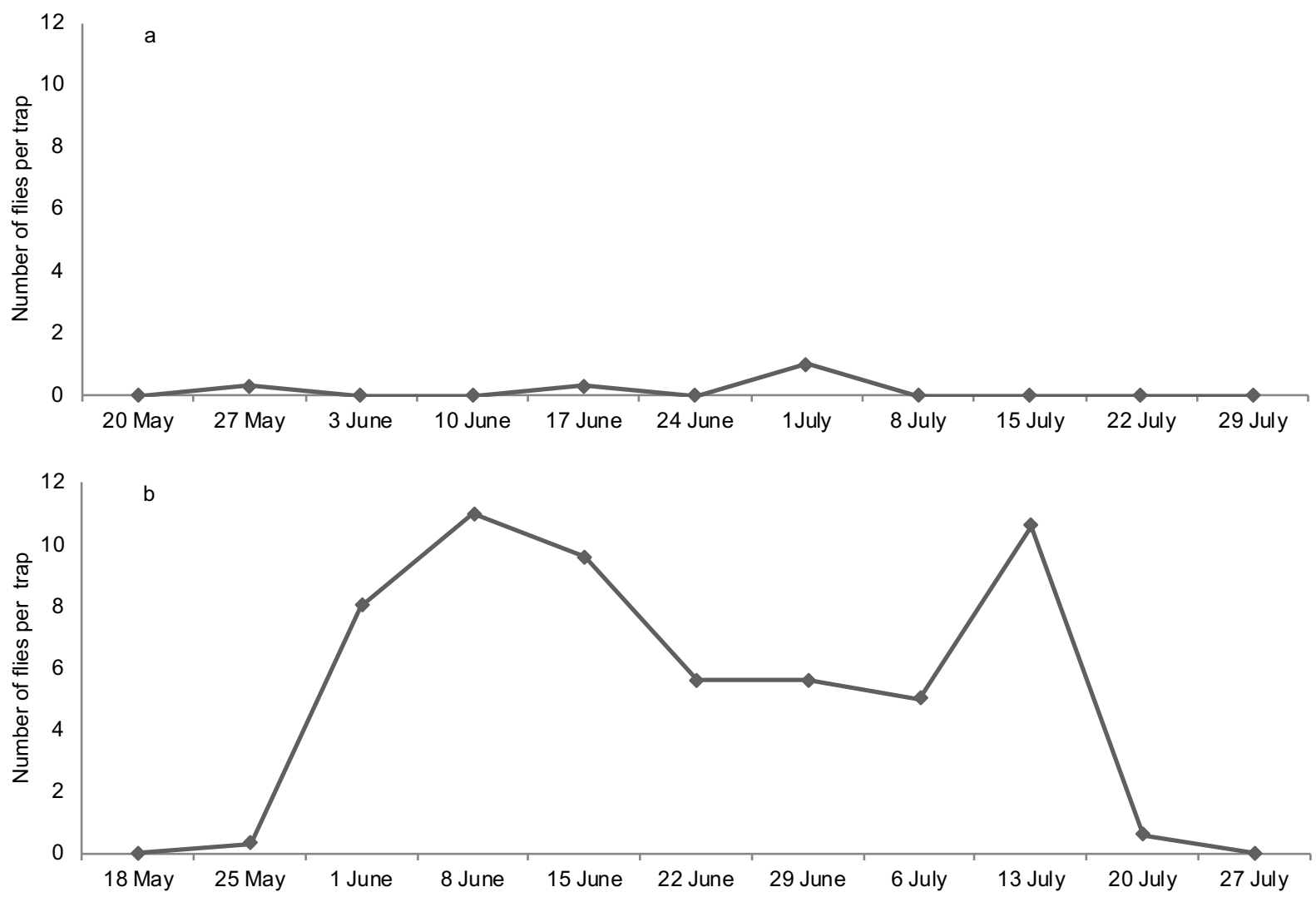

Figure 3. Flight activity of Rhagoletis cerasi at Darboğaz in a) 2015, and b) 2016.

\section{Evaluation of methods to control Rhagoletis cerasi}

At both Pozantı and Darboğaz, significant differences between the treatments in the percentage of fruits damaged by the $R$. cerasi were recorded (Tables 3 and 4). Fruit damage was always significantly higher in the untreated control than the other treatments. At Pozantı, fruit damage in control plot was 9.1, 27.6 and $11.1 \%$ in 2015,2016 and 2017, respectively (Table 3). At Darboğaz, fruit damage in control was 7.5 and $11.6 \%$ in 2015 and 2016, respectively (Table 4).

At Pozantı, mass trapping was highly successful with only $4.5,1.5,0.8 \%$ fruit damage in 2015 , 2016 and 2017, respectively, and its efficacy was 50.7, 94.6, 92.7\% (Table 3).

At both Pozantı and Darboğaz, netting of trees prevented all damage, so the efficacy of the treatment was $100 \%$.

For textile mulch at Pozantı, the damage was 1.0, 4.4 and 2.2\%, with treatment efficacy of 89.0 , 84.7 and $80.3 \%$ in 2015, 2016 and 2017, respectively (Table 3). At Darboğaz, the damage was $2.9 \%$ in both two years, with efficacy of 61.6 and $74.6 \%$ in 2015 and 2016, respectively (Table 4).

For azadirachtin at Pozantı, the damage $1.5,7.8$ and $1.6 \%$, with efficacy of $83.6,71.9$ and $85.6 \%$ in 2015, 2016 and 2017, respectively. Whereas, with thiacloprid the damage was 3.1, 13.0 and $3.3 \%$, efficacy of 65.7, 52.9 and $70.8 \%$ in 2015, 2016 and 2017, respectively (Table 3). At Darboğaz with azadirachtin the damage was 2.0 and $5.5 \%$, with efficacy 73.3 and $53.1 \%$ in 2015 and 2016 , respectively, compared to damage of 4.5 and $2.5 \%$ with thiacloprid, with efficacy of 40.0 and $78.5 \%$, respectively (Table 4). 
Table 3. Damage rates (\%) determined for various control methods for Rhagoletis cerasi at Pozantı (2015-2017)

\begin{tabular}{|c|c|c|c|c|c|c|c|c|c|}
\hline \multirow{3}{*}{$\begin{array}{l}\text { Treatment } \\
\text { Mass trapping }\end{array}$} & \multicolumn{3}{|c|}{2015} & \multicolumn{3}{|c|}{2016} & \multicolumn{3}{|c|}{2017} \\
\hline & \multicolumn{2}{|c|}{$\begin{array}{c}\text { Damage (\%) } \\
\text { mean } \pm \mathrm{SE}^{*}\end{array}$} & \multirow{2}{*}{$\begin{array}{c}\text { Efficacy (\%) } \\
50.7\end{array}$} & \multicolumn{2}{|c|}{$\begin{array}{c}\text { Damage }(\%) \\
\text { mean } \pm S E *\end{array}$} & \multirow{2}{*}{$\begin{array}{c}\text { Efficacy (\%) } \\
94.6\end{array}$} & \multicolumn{2}{|c|}{$\begin{array}{c}\text { Damage }(\%) \\
\text { mean } \pm S E^{*}\end{array}$} & \multirow{2}{*}{$\begin{array}{c}\text { Efficacy (\%) } \\
92.7\end{array}$} \\
\hline & $4.5 \pm 1.03$ & $b^{*}$ & & $1.5 \pm 0.63$ & $e^{*}$ & & $0.8 \pm 0.30$ & $d^{*}$ & \\
\hline Thiacloprid & $3.1 \pm 0.97$ & b & 65.7 & $13.0 \pm 2.92$ & b & 52.9 & $3.3 \pm 0.37$ & $b$ & 70.8 \\
\hline Azadirachtin & $1.5 \pm 0.46$ & c & 83.6 & $7.8 \pm 1.58$ & c & 71.9 & $1.6 \pm 0.50$ & $c d$ & 85.6 \\
\hline Textile mulch & $1.0 \pm 0.53$ & c & 89.0 & $4.4 \pm 0.75$ & $d$ & 84.2 & $2.2 \pm 0.53$ & c & 80.3 \\
\hline Netting & $0.0 \pm 0.00$ & $d$ & 100.0 & $0.0 \pm 0.00$ & $f$ & 100.0 & $0.0 \pm 0.00$ & e & 100.0 \\
\hline Control & $9.1 \pm 2.90$ & a & & $27.6 \pm 3.99$ & a & & $11.1 \pm 1.93$ & a & \\
\hline
\end{tabular}

* Difference between means followed by the same letter within a column are not statistically significant based on Duncan's test $(P<0.05)$.

Table 4. Damage rates (\%) determined for various control methods for Rhagoletis cerasi at Darboğaz (2015 and 2016)

\begin{tabular}{lcccccc}
\hline & \multicolumn{3}{c}{2015} & \multicolumn{3}{c}{2016} \\
\hline Treatment & $\begin{array}{l}\text { Damage (\%) } \\
\text { mean } \pm \text { SE ** }\end{array}$ & Efficacy (\%) & $\begin{array}{l}\text { Damage (\%) } \\
\text { mean } \pm \text { SE ** }\end{array}$ & Efficacy (\%) \\
\hline Thiacloprid & $4.5 \pm 0.96$ & b $^{* *}$ & 40.0 & $2.5 \pm 1.04$ & c $^{* *}$ & 78.5 \\
Azadirachtin & $2.0 \pm 0.65$ & $\mathrm{c}$ & 73.3 & $5.5 \pm 1.89$ & $\mathrm{~b}$ & 53.1 \\
Textile mulch & $2.9 \pm 0.93$ & $\mathrm{c}$ & 61.6 & $2.9 \pm 1.07$ & $\mathrm{c}$ & 74.6 \\
Netting & $0.0 \pm 0.00$ & $\mathrm{~d}$ & 100.0 & $0.0 \pm 0.00$ & $\mathrm{~d}$ & 100.0 \\
Control & $7.5 \pm 0.65$ & $\mathrm{a}$ & & $11.6 \pm 2.10$ & $\mathrm{a}$ & \\
\hline
\end{tabular}

* There was no orchard suitable for mass trapping technique at Darboğaz.

** Difference between means followed by the same letter within a column are not statistically significant based on Duncan's test $(P<0.05)$.

\section{Discussion}

This study showed that the adult population density of $R$. cerasi in the orchard corresponded to the phenology of cherry trees. Also, the data collected at Pozantı showed that even at low population density of $R$. cerasi damage occurred, so there needs to be a zero tolerance for this pest. One reason for this is that $R$. cerasi usually pupate directly under the canopy of the cherry trees, especially under the south and southeast parts of the tree where the highest fruit infestation levels are observed (Engel, 1969). For pests that overwinter beneath perennial hosts, there appears to be little impetus for adults to move long distances. Cherry fruit fly does not move far and usually completes its maturation in the fresh shoots of the tree. Adults after mating firstly lay eggs in the fruit on that tree, but when they cannot find fruit, they only move to the nearest tree with fruit to lay their eggs. Cherry fruit fly adults do not tend to leave the environment as long as they can find suitable fruit for maturation, food and egg laying. Researchers reported which their movements are associated with normal activities of feeding, oviposition and mating (Wiesmann, 1934; Katsoyannos et al., 1986). These movements show a daily periodicity and rarely take individuals far from their host plants (Haisch et al., 1976; Katsoyannos et al., 1986). For these reasons, it is thought that if the food-attracting odors from traps are not strong, the flies do not head for such traps. Therefore, the adult density may be low in trees in which traps are hung. Particularly in control studies (mass capture technique), a large number of such traps need to be hung. At Darboğaz, first adult emergence was recorded when the fruits were small and green. After the harvest, some adults continued to be seen in the orchard, so it was concluded that these $R$. cerasi were living on alternative hosts (wild cherry, mahaleb trees and sour cherry trees) around the trial area. 
When we compared the two orchards, it was observed that the first adult capture dates were very close to each other, although there was an altitude difference of $400 \mathrm{~m}$ between these orchards. This situation might be because some adults which emerged early from the diapause at Darboğaz. Ulusoy \& Vatansever (2001) reported that $R$. cerasi adults can be seen between the second and third weeks of May at Pozantı and they can have emerged after another 10-15 $d$ at Pozantı due to altitude and climatic conditions at Darboğaz. It has been reported that adults appear a little later in higher altitude areas than in lower altitudes areas, due to exposure to lower temperatures during post-diapause development (Kovancı \& Kovancı, 2006). The cause of the early emergence of adults at Darboğaz might be that the average winter temperature is low and the temperature rises above $7^{\circ} \mathrm{C}$ per day in March-April after they have completing the post-diapause development. This conclusion would be consistent with the causes of early emergence of the pest mentioned in the literature.

In both orchards, there were significant differences between treatments in the percentage of fruit damaged. Fruit damage was always significantly higher in the untreated control than the other methods. In both orchards, netting of trees was $100 \%$ effective and clearly the best option for fruit fly-free cherry production in ordinary and organic production and should be adopted as routine practice. This result was consistent with the reports of some other researchers. The high protection provides completes control with no side effects due to aphids or fruit rot being reported (Caruso \& Cera, 2004; Charlot \& Weydert, 2013). The results of this and earlier studies are consistent and it is recommended that been thinked a technique that should be transferred to practice.

It is clearly seen that mass trapping technique with yellow sticky traps is an effective method for cherry fruit fly control. The results were quite good when compared with the untreated control and insecticide application, and demonstrated that mass trapping for control of cherry fruit fly is a real alternative. This is consistent with other research that used yellow sticky traps in the control of cherry fruit fly which successfully prevented infestation of cherry fruit (Tezcan \& Gülperçin, 2000; Tezcan et al., 2000; Ulusoy et al., 2001; Grassi et al., 2010).

Fabric mulching of the soil surface under the cherry trees was the next most successful method after netting of trees at both locations. Compared to insecticide application mulching was more successful with efficacy of $80-89 \%$ at Pozantı (vs. $53-71 \%$ with thiacloprid) and $62-75 \%$ at Darboğaz (vs. $40-79 \%$ with thiacloprid). One reasons for the success of the mulch is the biology of the pest, which generally only flies short distances. The pest pupates in the ground directly under the cherry tree crown so is preveted from emerging even if suitable conditions occur in the spring. Daniel \& Baker (2013) studied the general potential of soil treatments and dispersal and flight behavior of $R$. cerasi within orchards. Their experiments using netting to cover the soil were conducted in two orchards with different pest population densities over two years. The netting reduced flight activity by $77 \%$ and fruit infestation by $91 \%$. Therefore, it is reasonable to conclude that mulch application is a viable alternative to insecticide application. Therefore, given that mulch application can also control weeds and reduce water loss from the soil, it should be considered as a cultural control method in organic agriculture. The ability of mulch to prevent of weed emergence in a range or crops and to reduce soil water loss by evaporation had been confirm in a number of studies (Asiegbu, 1991; Monks et al., 1997; Kitiş, 2002; Kitiş et al., 2017).

In conclusion, the best results were obtained from netting $(100 \%)$ followed by mass capture technique (93-95\%) and mulch application (62-89\%). The plant-based insecticide, azadirachtin was more effective than the synthetic insecticide, thiacloprid, which gave the lowest level of control. Mass capture and mulch application were shown to be superior than plant-based and synthetic insecticides. In light of these results, we can conclude that the cultural methods are viable alternatives to insecticide application.

\section{Acknowledgments}

This study is the $\mathrm{PhD}$ project of senior author and was supported by Çukurova University as scientific research project number FDK-2015-3200. 


\section{References}

Abbott, W. S., 1925. A method of computing the effectiveness of an insecticide. Journal of Economic Entomology, 18 (2): 265-267.

Asiegbu, J. E., 1991. Response of tomato and eggplant to mulching and nitrogen fertilization under tropical conditions. Scientia Horticulturae, 46 (1-2): 33-41.

Boller, E. F., 1966. Der Einfluss natürlicher Reduktionsverfahren auf die Kirschenfliege Rhagoletis cerasi L. in der Nordwestschweiz, unter besonderer Berücksichtigung des Puppenstadiums. Revue Suisse d'Agriculture (Schweiz. Landw. Forsch.), 5: 154-210.

Boller, E. F. \& R. J. Prokopy, 1976. Bionomics and management of Rhagoletis. Annual Review of Entomology, 21 (1): 223-246.

Caruso, S. \& M. C. Cera, 2004. Control strategies for the cherry fruit fly (Rhagoletis cerasi) in organic farming. Integrated Plant Protection in Stone Fruit, IOBC/ WPRS Bulletin, 27 (5): 99-104.

Charlot, G. \& C. Weydert, 2013. "Nets and covers to protect cherry trees from rain and insects, 97-102". VII International Cherry Symposium (23-27 June 2013, Plasencia (Spain)), 680 pp.

Daniel, C. \& B. Baker, 2013. Dispersal of Rhagoletis cerasi in commercial cherry orchards: Efficacy of soil covering nets for cherry fruit fly control. Insects, 4 (1): 168-176.

Daniel, C. \& E. Wyss, 2003. "Neue Wege zur Regulierung der Kirschfruchtfliege Rhagoletis cerasi in der biologischen Süsskirschenproduktion. [New approaches to control the cherry fruit fly Rhagoletis cerasi in organic cherry production.], 541-542". Paper at: 7. Wissenschaftstagung zum ökologischen Landbau: Ökologischer Landbau der Zukunft, A-Wien, Institut für ökologischen Landbau (24-26. February 2003, Wien, Universität für Bodenkultur, Wien), $700 \mathrm{pp}$.

Engel, H., 1969. Versuche zur bekämpfung der kirschfruchtfliege mit leimtafeln. Gesunde Pflanzen, 21: $197-202$.

Grassi, A., D. Profaizer, R. Maines \& G. Visintainer, 2010. "An experience of cherry fruit fly Rhagoletis cerasi L. control with nets in Trentino, Italy Eco-Fruit, 259-263". Proceedings $14^{\text {th }}$ International Conference on Organic Fruit-Growing University of Hohenhaim (22-24 February 2010, Stuttgart, Germany), 414 pp.

Haisch, A., S. Forster \& J. Kamm, 1976. Experimentelle bestimmung der flugdisposition von kirschenfliegen Rhagoletis cerasi L. (Dipt.:Trypetidae). Anzeiger für Schädlingskunde 49 (2): 17-21.

Headrick, D. H. \& R. D. Goeden, 1998. The biology of non-frugivorous tephritid fruit flies. Annual Review of Entomology, 43 (1): 217-241.

Katsoyannos, B. I., E. F. Boller \& G. Benz, 1986. The behavior of the cherry fruit fly, Rhagoletis cerasi L., in its hostplant selection and its dispersal. Mitteilungen der Schweizerischen Entomologischen Gesellschaft, 59: 315-335.

Kitiş, Y. E., 2002. Isparta İli Domates Ekiliş Alanlarındaki Yabancı Otların, Rastlama Sıklıklarının ve Yoğunluklarının Belirlenmesi ve Plastik Toprak Örtülerinin Yabancı ot Kontrolü ve Domates Verimine Etkileri. Süleyman Demirel Üniversitesi, Fen Bilimleri Enstitüsü, (Basılmamış) Yüksek Lisans Tezi, Isparta, Turkey, 120 pp.

Kitiş, Y. E., O. Kolören \& F. N. Uygur, 2017. The effects of mulch textile application on weed control and mandarin growing in newly established mandarin orchard. Turkish Journal of Agriculture-Food Science and Technology, 5 (6): 568-580.

Kovancı, O. B. \& B. Kovancı, 2006. Effect of altitude on seasonal flight activity of Rhagoletis cerasi flies (Diptera: Tephritidae). Bulletin of Entomological Research, 96 (4): 345-351.

Leski, R., 1963. Studia nad biologia i ecologia nasionnicy tzresniowki Rhagoletis cerasi L. (Diptera: Trypetidae). Polskıe Pısmo Entomologıczne Ser. B, 3 (4): 153-240.

Mik, J., 1898. Zur biologie von Rhagoletis cerasi L. nebst einigen bemerkungen über die larven und puparien der trypetiden und über die fühler der musciden-larven. Wiener Entomologische Zeitung, 17: 279-313.

Monks, C. D., D. W. Monks, T. Basden, A. Selders, S. Poland \& E. Rayburn, 1997. Soil temperature, soil moisture, weed control and tomato (Lycopersicon esculentum) response to mulching. Weed Technology, 11 (3): 561-566. 
Ranner, H., 1988. Untersuchungen zur Biologie und Bekämpfung der Kirschfruchtfliege, Rhagoletis cerasi L. (Diptera, Trypetidae)-IV. Statistiche Auswertung von Kreuzenversuchen mit Kirschfliegen verschiedenen Alters and Puppengewichts, verschiedener Wirtspflanzenherkunft und Rassenzugehörigkeit. Pflanzenschutzberichte, 49: 74-86.

Tezcan, S. \& N. Gülperçin, 2000. "İzmir ve Manisa illeri ekolojik kiraz üretim bahçelerinin ana zararlılarından Kiraz sineği (Rhagoletis cerasi L.) (Diptera, Tephritidae) ile savaşta sarı yapışkan tuzaklardan yararlanma olanakları, 167-176". Türkiye 4. Entomoloji Kongresi Bildirileri, (12-15 September 2000, Kuşadası, Aydın, Turkey), 570 pp.

Tezcan, S., A. Mısırlı, B. Okur, M. A. UI, A. Olgun, H. Demirkan, A. Ünal, N. Eryüce, C. Harputlu, N. Çetinkaya, U. Aksoy, D. Anaç, B. Çokuysal \& H. Çakıcı, 2000. "Organic cherry production in western Turkey, 2". 13th International IFOAM Scientific Conference (28-31 August 2000, Basel, Switzerland), 762 pp.

Thiem, H., 1932. Heckenkirschen und sauerdorn als wirtspflanzen der kirschfruchtfliege (Rhagoletis cerasi L.). Nachrichtenblatt des Deutschen Pflanzenschutzdienstes, 12: 41-43.

Thiem, H., 1934. Beiträge zur epidemiologie und bekämpfung der kirschfruchtfliege (Rhagoletis cerasi L.). Arbeitsgemeinschaft Physiologischer und Angewandter Entomologie Berlin-Dahlem, 1: 7-79.

Thiem, H., 1939. Über die bedeutung der wilden wirtspflanzen der kirschfruchtfliege (Rhagoletis cerasi L.) für die verbreitung und bekämpfung des schädlings. Arbeitsgemeinschaft Physiologischer und Angewandter Entomologie Berlin-Dahlem, 6: 350-359.

Ulusoy, M. R. \& G. Vatansever, 2001. "Ulukışla (Niğde) - Pozantı (Adana) yöresi kiraz bahçelerinde kiraz sineği Rhagoletis cerasi L. (Diptera: Tephritidae)' nin popülasyon gelişmesi ve savaşım zamanının belirlenmesi, 537544". 1. Sert Çekirdekli Meyve Sempozyumu (25-28 September 2001, Yalova, Turkey), 610 pp.

Ulusoy, M. R., G. Vatansever \& N. Uygun, 1999. Ulukışla (Niğde) ve Pozantı (Adana) yöresinde kirazlarda zararlı olan türler, doğal düşmanları ve önemlileri üzerindeki gözlemler. Türkiye Entomoloji Dergisi, 23 (2): 111-120.

Ulusoy, M. R., G. Vatansever \& N. Uygun, 2001. “Kiraz sineği Rhagoletis cerasi L. (Diptera: Tephritidae)' ye karşı en etkili savaşım yönteminin belirlenmesi, 529-536”. 1. Sert Çekirdekli Meyve Sempozyumu (25-28 September 2001, Yalova, Turkey), 610 pp.

Vogt, H., 2002. Expertenkolloquium Kirschfruchtfliege. BBA Dossenheim, 27-28 November 2001. Nachrichtenblatt des Deutschen Pflanzenschutzdienstes, 54: 77-79.

White, I. M. \& M. M. Elson-Harris, 1992. Fruit Flies of Economic Significance: Their Identification and Bionomics; CAB International, Wallingford, Oxon, UK, $600 \mathrm{pp}$.

Wiesmann, R., 1934. Untersuchungen über die Lebensgeschichte und Bekämpfung der Kirschenfliege Rhagoletis cerasi Linné-II. Mitteilung. Landwirtschaftliches Jahrbuch der Schweiz, 48: 281-338.

Wiesmann, R., 1938. Befällt die kirschfliege ausser der kirsche auch andere wirte und welche bedeutung haben diese wirte. Schweizer Zeitschrift für Obst- und Weinbau, 47: 348-352. 